\title{
Effect of Solid Nanoparticle of Indomethacin on Therapy for Rheumatoid Arthritis in Adjuvant-Induced Arthritis Rat
}

\author{
Noriaki Nagai and Yoshimasa Ito* \\ Faculty of Pharmacy, Kinki University; 3-4-1 Kowakae, Higashi-Osaka, Osaka 577-8502, Japan. \\ Received November 25, 2013; accepted April 21, 2014
}

We designed new oral formulations containing indomethacin (IMC) solid nanoparticles, and investigate their usefulness by evaluating bioavailability and gastrointestinal lesions. The IMC solid nanoparticles were prepared using methylcellulose (MC), 2-hydroxypropyl- $\beta$-cyclodextrin (HPBCD), and the bead mill method,

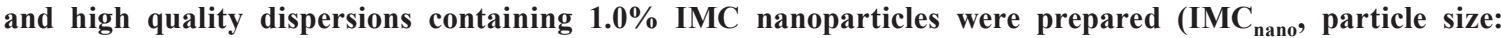
$76 \pm 58 \mathrm{~nm}$, means \pm S.D.). The fate of serum IMC and the induction of paw edema in adjuvant-induced arthritis (AA) rats receiving low-doses $\mathrm{IMC}_{\text {nano }}(0.4 \mathrm{mg} / \mathrm{kg})$ were similar to those following the administration of a therapeutic dose of conventional IMC prepared with MC and HPßCD (conventional IMC, $2 \mathrm{mg} / \mathrm{kg}$ ), and

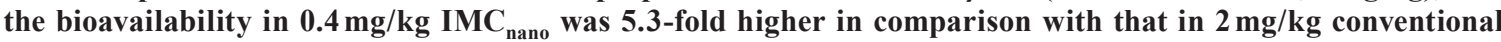
IMC. IMC-induced gastrointestinal lesions in AA rats administered $I_{M C}(8 \mathrm{mg} / \mathrm{kg})$, in consideration of bioavailability, were significantly less than for conventional IMC $(40 \mathrm{mg} / \mathrm{kg})$. On the other hand, the toxicity caused by conventional IMC and $\mathrm{IMC}_{\text {nano }}$ was similar in Caco-2 cells. It is possible that the oral administration of IMC solid nanoparticles will show increased effectiveness in treating RA without causing IMC-induced gastrointestinal lesions, since the bioavailability is higher than that of conventional IMC. An oral drug delivery system using drug nanoparticles may expand the usage of NSAIDs for therapy in the inflammatory field.

Key words nanoparticle; indomethacin; bioavailability; gastrointestinal lesion; adjuvant-induced arthritis

Arthritis is a chronic disease that affects several parts of the joints including the cartilage, synovium, tendons and muscles. Rheumatoid arthritis (RA) is a specific type of arthritis, and is a complex chronic inflammatory disease dependent on multiple interacting environmental and genetic factors, making it difficult to understand its pathogenesis and thereby to find effective therapies. ${ }^{1)}$ In treatments for RA, the focus is on the reduction of pain, inflammation and joint damage. The principal pharmacological agents are nonsteroidal anti-inflammatory drugs (NSAIDs), disease-modifying antirheumatic drugs, glucocorticoids and specific inhibitors of the mediator response. ${ }^{2)}$ It is well known, however, that these drugs have significant side effects. ${ }^{3-8)}$ Gastroenteropathy is the most common side effect among patients taking NSAIDs, and RA patients taking NSAIDs are more susceptible to NSAIDsinduced gastrointestinal lesions in comparison with other patients. $^{3-7,9)}$ NSAIDs-induced gastric lesions are believed to involve the depletion of endogenous prostaglandins (PG) via the inhibition of cyclooxygenase, and an overproduction of nitric oxide (NO) via inducible NO synthase (iNOS). ${ }^{3,6,10,11)}$ On the other hand, a number of elements, such as bacterial flora, neutrophils and iNOS, in addition to the depletion of endogenous PGs are involved in the pathogenesis of intestinal ulceration induced by NSAIDs, ${ }^{11-15)}$ and the presence of enterobacteria is essential for NSAID-induced ulceration to occur in the small intestine. ${ }^{11,14)}$ Kato et al. reported that the overproduction of NO plays a key pathogenic role in both the gastric and small intestinal ulcerogenic response to indomethacin (IMC) in RA model rats, and these gastrointestinal lesions increased in number with dose of oral administration. ${ }^{3,5-7)}$ Therefore, a decrease in amount administered orally by improving bioavailability may suppress the development of both of gastric and small intestinal ulcers in response to NSAIDs in RA patients.

The authors declare no conflict of interest
Recently, strategies using micro/nanoparticles have been developed and investigated, and it was reported that these strategies increase bioavailability and usefulness of drug. ${ }^{16-18)}$ Implants fabricated using the biodegradable polymer PLGA [poly(DL-lactide-co-glycolide)] with mean particle diameters of $50-200 \mathrm{~nm}$ have been widely utilized as carriers for bioactive molecules and present a possible solution to limitations surrounding ocular drug penetration. ${ }^{19-22)}$ In addition, Sha et $a{ }^{18)}$ developed a newly designed oral nanotherapeutic using redox nanoparticles $\left(\mathrm{RNP}^{\mathrm{O}}\right)$ with the potential to scavenge reactive oxygen species including nitroxide radicals for the treatment of inflammation in the gastrointestinal tract. $\mathrm{RNP}^{\mathrm{O}}$ is a core-shell-type polymeric micelle prepared by the self-assembly of methoxy-poly(ethylene glycol)- $b$-poly[4(2,2,6,6-tetramethylpiperidine-1-oxyl)oxymethyl-styrene]. It is expected that drug systems using nanoparticles may provide an alternative strategy for increasing drug bioavailability. ${ }^{19-22)}$ On the other hand, we have also developed methods to prepare tranilast solid nanoparticles by a bead mill method, and showed that these solid nanoparticles enhance drug bioavailability. ${ }^{23,24)}$ It is possible that decreasing the amount of orally administered NSAIDs by improving their bioavailability may lead to an expansion of their usage as therapy for RA patients.

Here, we have designed new oral formulations containing IMC solid nanoparticles, and investigated their usefulness by evaluating the drug bioavailability and gastrointestinal ulcerogenic responses.

\section{MATERIALS AND METHODS}

Animals and Materials Male Dark Agouti (DA) rats, aged 6 to 13 weeks, were housed under standard conditions $\left(12 \mathrm{~h} / \mathrm{d}\right.$ fluorescent light (07:00-19:00), $25^{\circ} \mathrm{C}$ room temperature), and allowed free access to a commercial diet (CE-2, Clea Japan Inc., Tokyo, Japan) and water. All procedures were 
performed in accordance with the Kinki University Faculty of Pharmacy Committee Guidelines for the Care and Use of Laboratory Animals. 2-Hydroxypropyl- $\beta$-cyclodextrin ( $\mathrm{HP} \beta \mathrm{CD}$, average molar substitution, 0.6; average molecular weight (MW), 1380) was purchased from Nihon Shokuhin Kako Co., Ltd. (Tokyo, Japan). Low-substituted methylcellulose (MC, METOLOSE SM-4, average viscosity, $4 \mathrm{~Pa} \cdot \mathrm{s}$ at $20^{\circ} \mathrm{C}$ ) was provide from Shin-Etsu Chemical Co., Ltd. (Tokyo, Japan). Conventional IMC (solid, IMC microparticles, 17.2 $\pm 12.8 \mu \mathrm{m}$, means \pm S.D.) was purchased from Wako Pure Chemical Industries, Ltd. (Osaka, Japan). All other chemicals used were of the highest purity commercially available.

Preparation of IMC Solid Nanoparticles IMC solid nanoparticles were prepared using zirconia beads and Bead Smash 12 (a bead mill, Wakenyaku Co., Ltd., Kyoto, Japan). ${ }^{23,24)}$ Zirconia beads (diameter: $2 \mathrm{~mm}$ ) were added to the IMC microparticles with or without MC, and the mixtures were crushed with the Bead Smash 12 for 30s (3000 rpm, $\left.4^{\circ} \mathrm{C}\right)$. The mixtures were then dispersed in saline with or without $5 \% \mathrm{HP} \beta \mathrm{CD}$, and crushed again with the Bead Smash $12\left(5500 \mathrm{rpm}, 30 \mathrm{~s} \times 15\right.$ times, $\left.4^{\circ} \mathrm{C}\right)$ in the presence of zirconia beads (diameter: $0.1 \mathrm{~mm}$ ). The compositions of the dispersions containing IMC are shown in Table 1. The $\mathrm{pH}$ was 6.5 for both dispersions containing IMC micro- or nanoparticles. The particle size was measured using a nanoparticle size analyzer SALD-7100 (Shimadzu Corp., Kyoto, Japan; refractive index $1.60-0.10 \mathrm{i})$. The solubility of IMC in saline with and without $5 \% \mathrm{HP} \beta \mathrm{CD}$ was $0.003 \%$ and $0.012 \%$, respectively (the inclusion complex by $5 \%$ HP $\beta$ CD was $0.009 \%$ ).

Stability of Drug Dispersions in IMC Formulations Three milliliters of dispersions containing IMC as described in Table 1 were incubated in $5 \mathrm{~mL}$ test tubes in the dark at $20^{\circ} \mathrm{C}$ for $14 \mathrm{~d}$, after which $50 \mu \mathrm{L}$ sample solutions were withdrawn from $5 \mathrm{~mm}$ under the surface at the indicated time intervals (total height of liquid before withdrawn of samples was $4 \mathrm{~cm}$ ). The IMC concentrations in the samples were determined by the following HPLC method. Fifty microliters of samples was added to $100 \mu \mathrm{L}$ methanol containing $0.1 \mu \mathrm{g}$ propyl $p$-hydroxybenzoate (internal standard), and the mixture was filtered through a Chromatodisk 4A (pore size $0.45 \mu \mathrm{m}$, Kurabo Industries Ltd., Osaka, Japan). The filtered solution $(10 \mu \mathrm{L})$ was injected into an Inertsil ${ }^{\circledR}$ ODS-3 $(3 \mu \mathrm{m}$, column size: $2.1 \mathrm{~mm} \times 50 \mathrm{~mm}$ ) column (GL Science Co., Inc., Tokyo, Japan) on a Shimadzu LC-20AT system equipped with a column oven CTO-20 A (Shimadzu Corp.). The mobile phase consisted of acetonitrile $-50 \mathrm{~mm}$ acetic acid $(40: 60, \mathrm{v} / \mathrm{v})$ at a flow rate of $0.25 \mathrm{~mL} / \mathrm{min}$; the column temperature was $35^{\circ} \mathrm{C}$, and the wavelength for detection was $254 \mathrm{~nm}$.

Induction of Arthritis in DA Rats Arthritis was induced by the injection of $50 \mu \mathrm{L}$ of adjuvant, a suspension of $10 \mathrm{mg} /$ $\mathrm{mL}$ heat-killed Mycobacterium butyricum (Difco, Detroit, MI, U.S.A.) in Bayol F oil, into the plantar region of the right hind foot and tail of DA rats. The control group received $50 \mu \mathrm{L}$ of Bayol $\mathrm{F}$ oil. In this study, inflammation during the development of adjuvant-induced arthritis (AA) is assessed by measuring paw edema, which is one parameter of inflammation. The paw edema of arthritis was assessed by measuring the paw volume by plethysmometry, and was quantified by the following equation (Eq. 1):

paw edema $(\Delta \mathrm{mL})$

= paw volume of arthritis rat - paw volume of normal rat

The inflammatory scores are represented as $A U C_{\text {edema }}$ (the area under the paw volume-time curve). The $A U C_{\text {edema }}(A U C$ during $0-42 \mathrm{~d}$ ) was calculated from the following equation (Eq. 2):

$$
A U C_{\text {edema }}=\int_{0 \mathrm{~d}}^{42 \mathrm{~d}} V_{\text {edema }} \mathrm{d} t
$$

where $V$ and $t$ are the volume of paw edema and the days after adjuvant injection, respectively.

Administration of $\mathbf{I M C}_{\text {micro }}$ or $\mathbf{I M C}_{\text {nano }} \mathrm{IMC}_{\text {micro }}$ or $\mathrm{IMC}_{\text {nano }}$ as described in Table 1 was administered orally to rats once a day starting on the day following adjuvant injection and continued for $42 \mathrm{~d}$. The doses administered were a low dose $(0.4 \mathrm{mg} / \mathrm{kg})$ and a therapeutic dose $(2 \mathrm{mg} / \mathrm{kg})$ in this study.

Assay of Serum IMC Concentrations On the day before $\mathrm{IMC}_{\text {micro }}$ or $\mathrm{IMC}_{\text {nano }}$ administration, a cannula filled with $30 \mu \mathrm{g} / \mathrm{mL}$ heparin (silicone tubing; i.d. $0.5 \mathrm{~mm}$, o.d. $1.0 \mathrm{~mm}$ ) was inserted into the right jugular vein of $\mathrm{AA}$ rats under isoflurane anesthesia. $\mathrm{IMC}_{\text {micro }}$ or $\mathrm{IMC}_{\text {nano }}$ (both of $0.4,2 \mathrm{mg} /$ $\mathrm{kg}$ ) was administered orally to the AA rats $14 \mathrm{~d}$ after adjuvant injection (dose-volume $1 \mathrm{~mL} / \mathrm{kg}$ ). Venous blood $(200 \mu \mathrm{L})$ was collected at $0,0.25,0.5,1,2,3,4,5$ and $6 \mathrm{~h}$ after the oral administration of IMC from the jugular vein through the cannula. The blood was centrifuged at $3000 \mathrm{rpm}$ for $20 \mathrm{~min}$ at $4^{\circ} \mathrm{C}$, and the serum obtained was stored at $-80^{\circ} \mathrm{C}$ until IMC analysis by the HPLC method described above.

The IMC concentration in the serum after a single injection of $0.3 \mathrm{~mL}$ of IMC solution $(2 \mathrm{mg} / \mathrm{kg})$ into the femoral vein was analyzed by Eq. 3:

$$
C_{\mathrm{IMC}}=A \cdot \mathrm{e}^{-\alpha \cdot t}+B \cdot \mathrm{e}^{-\beta \cdot t}
$$

where $t$ is time $(0-6 \mathrm{~h})$ after IMC injection, and $C_{\mathrm{IMC}}$ is the concentration of IMC at the corresponding time. $\alpha$

\begin{tabular}{|c|c|c|c|c|c|c|}
\hline \multirow{2}{*}{ Formulation } & \multicolumn{3}{|c|}{ Content (w/v\%) } & \multirow{2}{*}{ Treatment } & \multicolumn{2}{|c|}{ Particle size $(\mu \mathrm{m})$} \\
\hline & IMC microparticles & $\mathrm{MC}$ & $\mathrm{HP} \beta \mathrm{CD}$ & & Immediately & $14 \mathrm{~d}$ after preparation \\
\hline $\mathrm{IMC}_{\text {micro }}$ & 1.0 & 0.5 & 5.0 & - & $17.2 \pm 12.8$ & $17.5 \pm 12.9$ \\
\hline Milled-IMC & 1.0 & - & - & Bead mill & - & - \\
\hline Milled-IMC $\mathrm{MC}_{\mathrm{MC}}$ & 1.0 & 0.5 & - & Bead mill & $0.19 \pm 0.11$ & $0.56 \pm 0.28$ \\
\hline $\mathrm{IMC}_{\text {nano }}$ & 1.0 & 0.5 & 5.0 & Bead mill & $0.076 \pm 0.058$ & $0.083 \pm 0.063$ \\
\hline
\end{tabular}

Table 1. Changes in IMC Particle Size in Formulations of Particle Dispersions Containing IMC $14 \mathrm{~d}$ after Treatment with a Bead Mill

IMC particle sizes and standard deviations of dispersions containing IMC as described in Table 1 were determined by a nanoparticle size analyzer SALD-7100 (refractive index $1.60-0.10 \mathrm{i})$. The data are presented as means \pm S.D. 
$\left(2.24 \pm 0.27 \mathrm{~h}^{-1}\right)$ and $\beta\left(0.35 \pm 0.033 \mathrm{~h}^{-1}\right)$ show the elimination rate constants in the first and second-phases (mean \pm S.E., $n=5)$, and $A(8.40 \pm 2.14 \mu \mathrm{g} / \mathrm{mL})$ and $B(4.35 \pm 1.39 \mu \mathrm{g} / \mathrm{mL})$ are the IMC concentrations in the $\alpha$ - and $\beta$-phases, respectively.

The serum IMC concentration data after the oral administration of $0.3 \mathrm{~mL}$ of $\mathrm{IMC}_{\text {micro }}$ or $\mathrm{IMC}_{\text {nano }}(2 \mathrm{mg} / \mathrm{kg})$ were analyzed by Eq. 4 (the each parameters were fixed with the value provided from the Eq. 3):

$$
\begin{aligned}
C_{\mathrm{IMC}}= & \frac{A \cdot k_{\mathrm{a}}}{k_{\mathrm{a}}-\alpha} \mathrm{e}^{-\alpha(t-\tau)}+\frac{B \cdot k_{\mathrm{a}}}{k_{\mathrm{a}}-\beta} \mathrm{e}^{-\beta(t-\tau)} \\
& -\left(\frac{A \cdot k_{\mathrm{a}}}{k_{\mathrm{a}}-\alpha}+\frac{B \cdot k_{\mathrm{a}}}{k_{\mathrm{a}}-\beta}\right) \mathrm{e}^{-k_{\mathrm{a}}(t-\tau)}
\end{aligned}
$$

where $C_{\mathrm{IMC}}$ is the IMC concentration in the serum, $k_{\mathrm{a}}$ is the absorption rate constant. A nonlinear least-squares computer program (MULTI) was employed for the calculation. ${ }^{25)}$

The area under the IMC concentration-time curve $(A U C)$, area under the first moment curve $(A U M C)$ mean residence time $(M R T)$ and absolute bioavailability (BA) were calculated according to the following equations (Eqs. 5-8):

$$
\begin{gathered}
A U C=\int_{0 \mathrm{~h}}^{6 \mathrm{~h}} C_{\mathrm{IMC}} \mathrm{d} t+\frac{C_{\mathrm{IMC} \text { at } 6 \mathrm{~h}}}{\beta} \\
A U M C=\int_{0 \mathrm{~h}}^{\infty \mathrm{h}} C_{\mathrm{IMC}} \cdot t \mathrm{~d} t \\
M R T=\frac{A U M C}{A U C} \\
B A=\frac{A U C_{\text {p.o. }} / \text { Dose }_{\text {p.o. }}}{A U C_{\text {i.v. }} / \text { Dose }_{\text {i.v. }}} \times 100
\end{gathered}
$$

Briefly, $A U C$ was determined according to the trapezoidal rule up to $6 \mathrm{~h}$, which was the time of the final IMC concentration measurement. The $A U C_{\text {p.o. }}$ and $A U C_{\text {i.v. }}$ are $A U C$ after oral and intravenous administrations, respectively.

Assay of the IMC Absorption Using in Situ Loop Technique Fourteen days after adjuvant injection, AA were fasted overnight, and anesthetized with isoflurane. A small midline incision allowed the gentle exposure of a $4-5-\mathrm{cm}$ target portion of intestine. This target small intestine, selected because of its suitable vasculature to collect venous blood, was washed gently and enough with saline solution. In addition, the bile duct was tied. An 8-cm length of silicon tubing (o.d: $2.0 \mathrm{~mm}$, i.d.: $1.0 \mathrm{~mm}$, TERUMO Corp., Tokyo, Japan) was inserted into one end of the intestine and tied securely with a surgical suture. The opposite end was tied and $1.5-2.0 \mathrm{~mL}$ $(15-20 \mathrm{mg} / \mathrm{rat})$ of $\mathrm{IMC}_{\text {micro }}$ or $\mathrm{IMC}_{\text {nano }}(1.0 \%)$ was injected into the intestine through the tube. Heparin $(10 \mathrm{mg} / \mathrm{kg})$ was injected in the femoral vein. The mesenteric vein was cannulated with an appropriate size of polyethylene tubing (Hibiki Co., Tokyo, Japan), and all venous blood was collected in a micro tube. $^{26,27)}$ This blood was centrifuged at $10000 \mathrm{rpm}$ for $30 \mathrm{~min}$ at $4^{\circ} \mathrm{C}$, and the IMC concentration in the serum obtained was determined by the HPLC method described above.

Evaluation of Gastric Mucosal Lesions The AA rats were fasted for $18 \mathrm{~h}$ before experiments, but had free access to water. The rats were administered $\mathrm{IMC}_{\text {micro }}$ or $\mathrm{IMC}_{\text {nano }}(8$ or $40 \mathrm{mg} / \mathrm{kg}$ ) orally, and killed under deep ether anesthesia
$6 \mathrm{~h}$ later. ${ }^{3,6,7)}$ The stomachs were excised, washed and fixed in $10 \%$ formalin solution, and the area of gastric glandular mucosal lesions was observed in digital photographs and quantified with Image $\mathrm{J}(\mathrm{NIH})$. Lesion area is expressed as a percentage of the total area of glandular stomach except the fundus.

Evaluation of Small Intestinal Ulcerogenic Lesions AA rats were administered $\mathrm{IMC}_{\text {micro }}$ or $\mathrm{IMC}_{\text {nano }}(8$ or $40 \mathrm{mg} / \mathrm{kg})$ orally, and killed under deep ether anesthesia $24 \mathrm{~h}$ later. $\left.{ }^{3,5}\right)$ The small intestines were excised, washed and fixed in $10 \%$ formalin solution, and the area of the intestinal ulcerogenic lesions was observed in digital photographs and Image J. The lesion area is expressed as a percentage of the total area of small intestine.

RNA Preparation The gastric mucosa and small intestine (epithelium) were removed, after which the lenses and retinas were isolated, and the samples were snap-frozen in liquid nitrogen. Total RNA was prepared from each individual lens and retina by the acid guanidium thiocyanate-phenol-chloroform extraction method using Trizol reagent (Life Technologies Inc., Rockville, U.S.A.). The purity and concentrations of RNA were determined spectrophotometrically. The $\mathrm{OD}_{260}$ $\mathrm{OD}_{280}$ values of all RNA used were greater than 1.8, which indicates low protein contamination and high purity RNA.

Quantitative Real-Time Reverse Transcription Polymerase Chain Reaction (RT-PCR) The RT reaction was performed using an RNA PCR Kit (AMV Ver 3.0, TaKaRa Bio Inc., Shiga, Japan). One microgram of total RNA was mixed with $3 \mu \mathrm{L}$ of $10 \mathrm{~mm}$ Tris- $\mathrm{HCl}$ buffer ( $\mathrm{pH} 8.3$ ) containing $5 \mathrm{~mm} \mathrm{MgCl}_{2}$ and $50 \mathrm{~mm} \mathrm{KCl}$. The following components were then added to give a final volume of $10 \mu \mathrm{L}$ : 1 unit $/ \mu \mathrm{L}$ RNase inhibitor, $10 \mathrm{~mm}$ deoxynucleotide triphosphate, $2.5 \mathrm{units} / \mu \mathrm{L}$ reverse transcriptase, and $0.125 \mu \mathrm{M}$ oligo dT-adaptor primer. The RT reaction was performed at $42^{\circ} \mathrm{C}$ for $15 \mathrm{~min}$, followed by $5 \mathrm{~min}$ at $95^{\circ} \mathrm{C}$. PCR reactions were performed using LightCycler FastStart DNA Master SYBR Green I according to the manufacturer's instructions (Roche Diagnostics Applied Science, Mannheim, Germany). Briefly, $2 \mu \mathrm{L}$ of cDNA was mixed with $2 \mu \mathrm{L}$ of reaction mixture, LightCycler FastStart DNA Master SYBR Green I Reaction Mix, containing FastStart Taq DNA Polymerase, reaction buffer, $\mathrm{MgCl}_{2}, \mathrm{SYBR}$ Green I dye, and deoxynucleotide triphosphate mix. The following components were then added to give a final volume of $20 \mu \mathrm{L}$ containing specific primers for iNOS or glyceraldehyde-3-phosophate dehydrogenase (GAPDH, $10 \mathrm{pmol}$ each). The following primers were used: 5'-GGA GAG ATT TTT CAC GAC ACC C-3' and 5'-CCA TGCATA ATT TGG ACT TGC A-3' for iNOS (GenBank accession No. NM_012611); and 5'-ACG GCACAG TCA AGG CTG AGA-3' and 5'-CGC TCC TGG AAG ATG GTG AT-3' for GAPDH (GenBank accession No. NM_017008). The PCR conditions were $95^{\circ} \mathrm{C}$ for $10 \mathrm{~min}, 50$ cycles of $95^{\circ} \mathrm{C}$ for $10 \mathrm{~s}$ (denaturing), $60^{\circ} \mathrm{C}$ for $10 \mathrm{~s}$ (annealing), and $72^{\circ} \mathrm{C}$ for $5 \mathrm{~s}$ (extension). The quantities of PCR products were measured fluorometrically in a real-time manner using a LightCycler DX 400 (Roche Diagnostics Applied Science, Mannheim, Germany). After completion of the PCR reactions, dissociation curves of the PCR products were generated using the LightCycler Software Version 4.0 program to detect nonspecific amplification, including primer-dimers, and to ascertain the quality of the amplification data. The differences in the threshold cycles for GAPDH and iNOS were used to calculate the levels 
of mRNA expression in the rats.

Measurement of Protein Protein levels in the gastric mucosa and small intestine (epithelium) of rats were determined according to the method of Bradford ${ }^{28)}$ using a Bio-Rad Protein Assay Kit (BIO-RAD, CA, U.S.A.) with bovine serum albumin as the standard.

Measurement of NO Levels The gastric mucosa and small intestine (epithelium) were excised from rats and stored at $-80^{\circ} \mathrm{C}$ until use. Tissue samples were homogenized in saline on ice, and centrifuged at $10000 \mathrm{rpm}$ for $15 \mathrm{~min}$ at $4^{\circ} \mathrm{C}$. The resultant supernatants were used for the measurement of NO levels. A concentric microdialysis probe (A-1-20-05, $5 \mathrm{~mm}$ in length; Eicom, Kyoto, Japan) was placed in the supernatant and perfused with Ringer's solution $(140 \mathrm{~mm} \mathrm{NaCl}, 4 \mathrm{~mm} \mathrm{KCl}$, $1.26 \mathrm{mM} \mathrm{CaCl}_{2}$, and $1.15 \mathrm{~mm} \mathrm{MgCl}_{2}, \mathrm{pH} 7.4$ ) at a constant flow rate of $2 \mu \mathrm{L} / \mathrm{min}$ using a micro syringe pump (ESP-64, Eicom). $\mathrm{NO}_{2}^{-}$and $\mathrm{NO}_{3}^{-}$in the supernatant were separated on a reverse-phase separation column packed with polystyrene polymer (NO-PAK, $4.6 \times 50 \mathrm{~mm}$, Eicom); $\mathrm{NO}_{3}{ }^{-}$was reduced to $\mathrm{NO}_{2}^{-}$in a reduction column packed with copper-plated cadmium filings (NO-RED, Eicom). $\mathrm{NO}_{2}{ }^{-}$was mixed with Griess reagent to form a purple azo dye in a reaction coil, and placed in a column oven set at $35^{\circ} \mathrm{C}$. The absorbance of the color product dye at $540 \mathrm{~nm}$ was determined on a flow-through spectrophotometer (NOD-10, Eicom). The mobile phase consisted of $10 \%$ methanol containing $0.15 \mathrm{M} \mathrm{NaCl}-\mathrm{NH}_{4} \mathrm{Cl}$ and $0.5 \mathrm{~g} / \mathrm{L} \mathrm{Na} \mathrm{Na}_{4}$-EDTA delivered by a pump at a rate of $0.33 \mathrm{~mL} /$ min. The Griess reagent, $1.25 \% \mathrm{HCl}$ containing $5 \mathrm{~g} / \mathrm{L}$ sulfanilamide with $0.25 \mathrm{~g} / \mathrm{L} N$-naphthylethylenediamine, was delivered at a rate of $0.1 \mathrm{~mL} / \mathrm{min}$. In this paper, the amounts of $\mathrm{NO}$ reflect the level of the $\mathrm{NO}_{2}^{-}$metabolite, which is produced from NO. ${ }^{7}$

Measurement of IMC Concentration in the Mucosal Membrane of Stomach and Small Intestine Following Oral
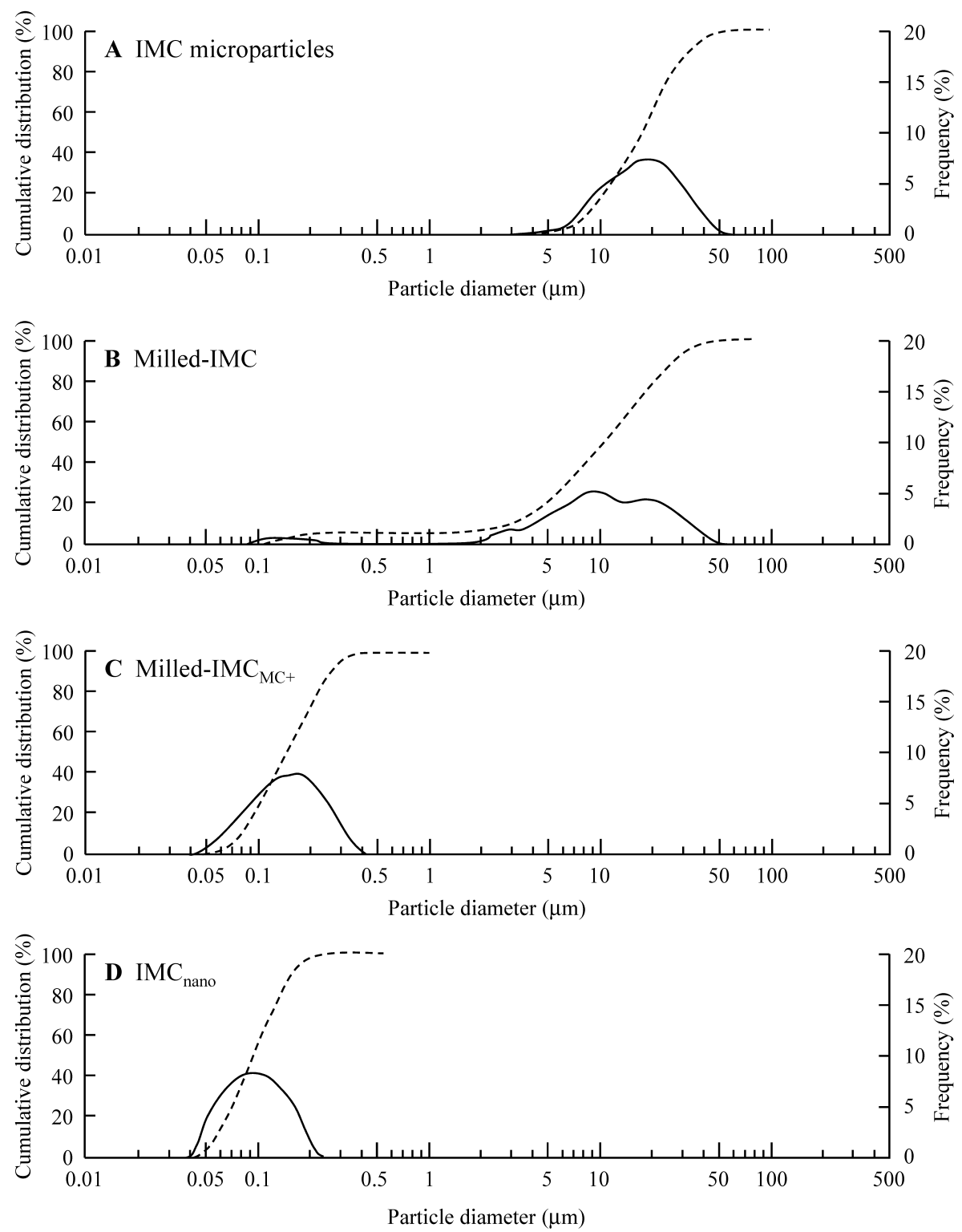

Fig. 1. Cumulative Size Distribution and Frequency of IMC Dispersions with or without MC, HP $\beta$ CD and Bead Mill Treatment

The compositions of the IMC dispersions are shown in Table 1. Particle size was determined using a nanoparticle size analyzer SALD-7100 (refractive index 1.60-0.10i). (A) Cumulative distribution and frequency of IMC microparticles, (B) cumulative distribution and frequency of Milled-IMC, (C) cumulative distribution and frequency of Milled-IMC $\mathrm{MC}$, (D) cumulative distribution and frequency of $\mathrm{IMC}_{\text {nano }}$. 
Administration The AA rats were fasted for $18 \mathrm{~h}$ before the experiments, but had free access to water. The rats were administered $\mathrm{IMC}_{\text {micro }}$ or $\mathrm{IMC}_{\text {nano }}(40 \mathrm{mg} / \mathrm{kg})$ orally, and killed under deep isoflurane anesthesia 3,6 and $12 \mathrm{~h}$ later. The stomachs, duodenum (lower $2 \mathrm{~cm}$ of the stomach), jejunum ( $40 \%$ of the upper part of small intestine, $28.1 \pm 3.9 \mathrm{~cm})$, and ileum $(60 \%$ of the lower part of small intestine, $40.1 \pm 7.2 \mathrm{~cm})$ were washed by saline, and these mucosal membrane were excised (mean \pm S.E., $n=25$ ). These samples were homogenized in methanol on ice, and centrifuged at $10000 \mathrm{rpm}$ for $15 \mathrm{~min}$ at $4^{\circ} \mathrm{C}$. IMC in the supernatant was analyzed by the HPLC method described above.

Stimulation Studies with Caco-2 Cells The Caco-2 cell line was used in this study. Caco-2 cells were cultured in Dulbecco's modified Eagle's medium (GIBCO, Tokyo, Japan) containing $10 \%(\mathrm{v} / \mathrm{v})$ heat-inactivated fetal bovine serum (GIBCO), 1\% non-essential amino acid solution (GIBCO), 1\% L-glutamine and $10 \mu \mathrm{g} / \mathrm{mL}$ streptomycin and $1000 \mathrm{IU} / \mathrm{mL}$ penicillin (GIBCO). Caco-2 cells $\left(1.5 \times 10^{4}\right.$ cells $)$ were seeded in 96-well microplates (IWAKI, Chiba, Japan). At $1 \mathrm{~d}$ after seeding, the medium was changed to medium containing $0-1 \%$ $\mathrm{IMC}_{\text {micro }}$ or $\mathrm{IMC}_{\text {nano, }}$, and the cells were incubated for $24 \mathrm{~h}$. In this study, we showed the concentration range $(0-0.16 \%)$ where cytotoxicity was seen (Fig. 6). Following stimulation, culture medium containing TetraColor One (SEIKAGAKU Co., Tokyo, Japan) was added, the absorbance at $490 \mathrm{~nm}$ was measured, and cell viability was calculated according to the manufacturer's instructions as represented by Eq. 9:

$$
\text { cell viability }(\%)=\mathrm{Abs}_{\text {treatment }} / \mathrm{Abs}_{\text {non-treatment }} \times 100
$$

Statistical Analysis All values are presented as mean \pm standard deviation (S.D.) or standard error of the mean (S.E.). Unpaired Student's $t$-test was used to evaluate statistical differences, and multiple groups were evaluated by one-way ANOVA followed by Dunnett's multiple comparison. The $p$ values less than 0.05 were considered significant.

\section{RESULTS}

Preparation of Dispersions Containing IMC Nanoparticles Figure 1 shows the particle size distribution of dispersions containing IMC as described in Table 1. The mean particle size using the IMC treated bead mill method was $15.8 \pm 14.3 \mu \mathrm{m}$ (Milled-IMC, means \pm S.D.), with the particle size being on the micrometer order (Fig. 1B). On the other hand, IMC particles obtained by the addition of MC and the bead mill method had a mean particle size of $190 \pm 110 \mathrm{~nm}$ (Milled-IMC $\mathrm{MC}_{\mathrm{MC}}$, means \pm S.D.). In addition, the mean particle size using the IMC treated bead mill method was $76 \pm 58 \mathrm{~nm}$ by the addition of both $\mathrm{MC}$ and $\mathrm{HP} \beta \mathrm{CD}\left(\mathrm{IMC}_{\text {nano, means }}\right.$, S.D.), and the mean particle size of $\mathrm{IMC}_{\text {nano }}$ was lower than that of Milled-IMC $\mathrm{MC}_{\mathrm{MC}}$. Figure 2 shows the stability of drug dispersions in $1.0 \%$ IMC formulation as described in Table 1. The $\mathrm{IMC}_{\text {micro }}$ preparation precipitated $4 \mathrm{~h}$ after preparation, and the stability of drug dispersions in IMC formulation was increased by the combination of added $\mathrm{MC}$ and the bead mill method. Furthermore, the addition of $\mathrm{HP} \beta \mathrm{CD}$ further enhanced the stability of drug dispersion in $\mathrm{IMC}_{\text {nano, }}$, and no precipitation was observed $14 \mathrm{~d}$ after preparation. Although the particle size of Milled-IMC $\mathrm{IC}_{\mathrm{MC}}$ increased to $0.56 \pm 0.28 \mu \mathrm{m}$

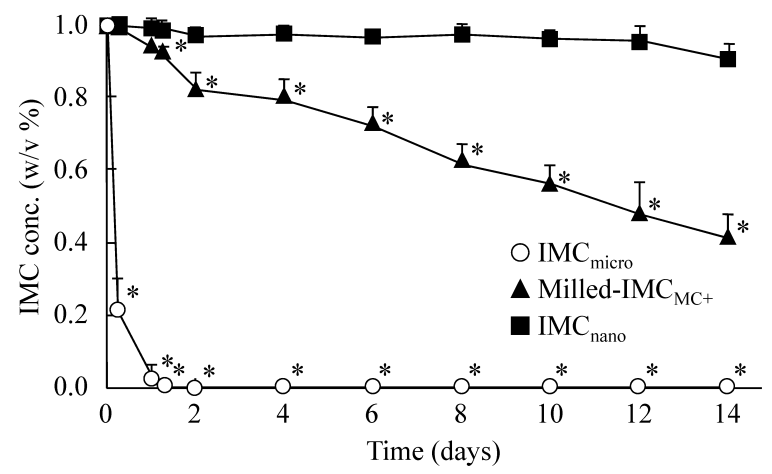

Fig. 2. Stability of Drug Dispersions in IMC Formulation with or without MC, $\mathrm{HP} \beta \mathrm{CD}$ and Bead Mill Treatment

One percent IMC dispersions were kept in the dark at $20^{\circ} \mathrm{C}$ for $14 \mathrm{~d}$, and the amounts of remaining IMC were determined at the indicated time points. The compositions of the IMC dispersions are shown in Table 1 . The data are presented as means \pm S.E. of 5 independent samples.

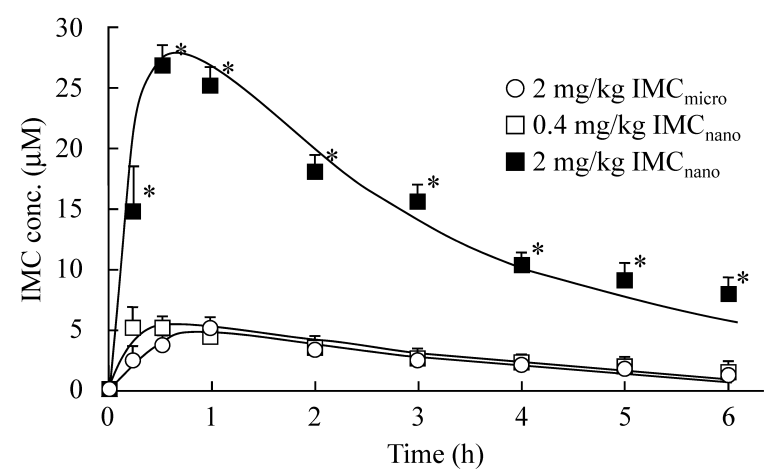

Fig. 3. Serum IMC Concentration Following the Oral Administration of $\mathrm{IMC}_{\text {micro }}$ or $\mathrm{IMC}_{\text {nano }}$ in AA Rats

Serum IMC concentration following the oral administration of IMC in AA rats. IMC, $0.4 \mathrm{mg} / \mathrm{kg}$ or $2 \mathrm{mg} / \mathrm{kg}$, was administered to AA rats $14 \mathrm{~d}$ after adjuvant injection. Solid lines present fitting curves calculated using Eq. 4 (see Materials and Methods). The data are presented as the means \pm S.E. of $6-7$ experiments. ${ }^{*} p<0.05$ vs. $\mathrm{IMC}_{\text {micro }}$-administered rats.

from $0.19 \pm 0.11 \mu \mathrm{m}$, there was no change in the particle size of $\mathrm{IMC}_{\text {nano }}$ between 0 and $14 \mathrm{~d}$ after preparation (Table 1).

Pharmacokinetics in the Oral Administration of Dispersions Containing IMC Nanoparticles Figure 3 shows the serum IMC concentrations following the oral administration of $\mathrm{IMC}_{\text {micro }}$ and $\mathrm{IMC}_{\text {nano }}$ at a low dose $(0.4 \mathrm{mg} / \mathrm{kg})$ or therapeutic dose $(2 \mathrm{mg} / \mathrm{kg})$ in AA rats $14 \mathrm{~d}$ after adjuvant injection, and Table 2 summarizes the pharmacokinetic parameters calculated from the in vivo intestinal penetration data. The serum IMC levels, absorption rate constant $\left(k_{\mathrm{a}}\right), A U C$ and $A U M C$ in AA rats administered $2 \mathrm{mg} / \mathrm{kg} \mathrm{IMC}_{\text {nano }}$ were all significantly higher than those in in rats administered $2 \mathrm{mg} / \mathrm{kg} \mathrm{IMC}_{\text {micro, }}$, and the $T_{\max }$ in the case of $\mathrm{IMC}_{\text {nano }}$ was faster than that in the case of $\mathrm{IMC}_{\text {micro }}$. On the other hand, there were no significant differences in the pharmacokinetic parameters $\left(C_{\max }, A U C\right.$, $A U M C$ and $M R T$ ) between the administration of low dose $\mathrm{IMC}_{\text {nano }}(0.4 \mathrm{mg} / \mathrm{kg})$ and therapeutic dose $\mathrm{IMC}_{\text {micro }}(2 \mathrm{mg} / \mathrm{kg})$. The bioavailability in the case of $0.4 \mathrm{mg} / \mathrm{kg} \mathrm{IMC}_{\text {nano }}$ was $5.3-$ fold higher than that in the case of $2 \mathrm{mg} / \mathrm{kg} \mathrm{IMC}$ micro.

Gastric and Small Intestinal Ulcerogenic Response to IMC in AA Rats Figure 4 shows the changes in gastrointestinal lesions and $\mathrm{NO}$ in $\mathrm{AA}$ rats administered $\mathrm{IMC}_{\text {micro }}$ and $\mathrm{IMC}_{\text {nano }}$. The oral administration of $\mathrm{IMC}_{\text {micro }}$ or $\mathrm{IMC}_{\text {nano }}$ $(40 \mathrm{mg} / \mathrm{kg})$ caused hemorrhagic lesions in both the gastric 
Table 2. Pharmacokinetic Parameters for Plasma IMC Concentration after Oral Administration of $\mathrm{IMC}_{\text {micro }}$ and IMC ${ }_{\text {nano }}$

\begin{tabular}{|c|c|c|c|c|c|c|c|}
\hline Rp. & $k_{\mathrm{a}}(\times 10 / \mathrm{h})$ & $T_{\max }(\mathrm{h})$ & $\begin{array}{c}C_{\max } \\
(\mathrm{nmol} / \mathrm{mL})\end{array}$ & $\begin{array}{c}A U C \\
(\mathrm{nmol} / \mathrm{mL} \cdot \mathrm{h})\end{array}$ & $\begin{array}{c}A U M C \\
\left(\mathrm{nmol} \cdot \mathrm{h}^{2} / \mathrm{mL}\right)\end{array}$ & $M R T(\mathrm{~h})$ & $\mathrm{BA}(\%)$ \\
\hline $\mathrm{IMC}_{\text {micro }}(2 \mathrm{mg} / \mathrm{kg})$ & $0.38 \pm 0.11$ & $0.92 \pm 0.09$ & $5.29 \pm 0.13$ & $19.11 \pm 1.93$ & $40.08 \pm 3.47$ & $2.29 \pm 0.08$ & $14.8 \pm 4.7$ \\
\hline $\mathrm{IMC}_{\text {nano }}(0.4 \mathrm{mg} / \mathrm{kg})$ & $1.21 \pm 0.49 *$ & $0.59 \pm 0.19 *$ & $5.37 \pm 0.49$ & $21.67 \pm 2.40$ & $48.43 \pm 4.96$ & $2.34 \pm 0.16$ & $78.8 \pm 9.3^{*}$ \\
\hline $\mathrm{IMC}_{\text {nano }}(2 \mathrm{mg} / \mathrm{kg})$ & $1.35 \pm 0.56^{*}$ & $0.53 \pm 0.31 *$ & $28.5 \pm 4.60 *, * *$ & $121.8 \pm 24.3^{*} * *$ & $321.5 \pm 63.8^{*, * *}$ & $2.46 \pm 0.24$ & $83.4 \pm 15.5^{*}$ \\
\hline
\end{tabular}

Dispersions containing IMC as described in Table 1 were administered orally to rats. Parameters were calculated according to Eqs. $4-8$ (see Materials and Methods). $\alpha$ $2.24 \pm 0.27 \mathrm{~h}^{-1}, \beta 0.35 \pm 0.033 \mathrm{~h}^{-1}, A 8.40 \pm 2.14 \mu \mathrm{g} / \mathrm{mL}, B \quad 4.35 \pm 1.39 \mu \mathrm{g} / \mathrm{mL}$. IMC $\mathrm{IMicro}_{\text {m }}, \mathrm{IMC}_{\text {micro }}$-administered $\mathrm{AA}$ rats; IMC $\mathrm{IMno}_{\text {nano }}, \mathrm{IMC}_{\text {nano }}$-administered $\mathrm{AA}$ rats. The data are presented as means \pm S.E. of $6-7$ independent rats. ${ }^{*} p<0.05$ vs. $2 \mathrm{mg} / \mathrm{kg} \mathrm{IMC}$ micro ${ }^{* *} p<0.05$ vs. $0.4 \mathrm{mg} / \mathrm{kg} \mathrm{IMC} \mathrm{IMano}_{\text {* }}$.
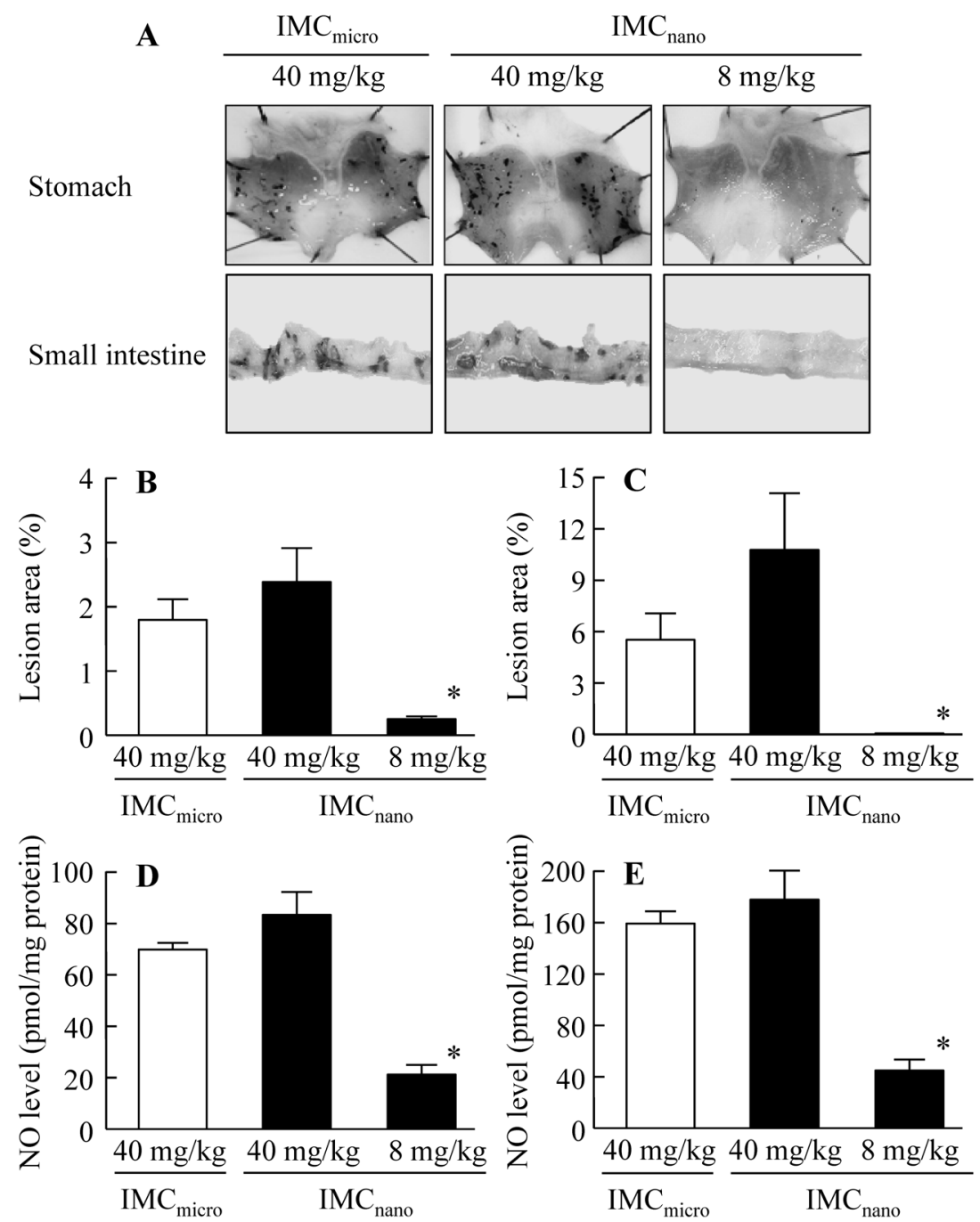

Fig. 4. Effect of Orally Administered $\mathrm{IMC}_{\text {micro }}$ or $\mathrm{IMC}_{\text {nano }}$ on Indomethacin-Induced Gastrointestinal Lesions in AA Rats

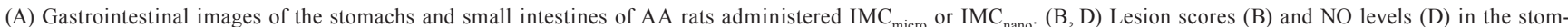
achs of AA rats administered $\mathrm{IMC}_{\text {micro }}$ or $\mathrm{IMC}_{\text {nano. }}$. AA rats $14 \mathrm{~d}$ after adjuvant injection were fasted for $18 \mathrm{~h}$ before the experiments. AA rats were orally administered IMC ( 8 or $40 \mathrm{mg} / \mathrm{kg})$, and killed $6 \mathrm{~h}$ later. (C, E) Lesion scores (C) an NO levels (E) in the small intestines of AA rats administered IMC ${ }_{\text {micro }}$ or IMC ${ }_{\text {nano }}$ AA rats $14 \mathrm{~d}$ after adjuvant injection were orally administered IMC $(8 \mathrm{or} 40 \mathrm{mg} / \mathrm{kg})$, and killed $24 \mathrm{~h}$ later. The data are presented as the means $\pm \mathrm{S} . \mathrm{E}$. of 5 experiments. $* p<0.05 v s .40 \mathrm{mg} / \mathrm{kg}$ $\mathrm{IMC}_{\text {micro }}$-administered rats.

mucosa and small intestine of AA rats $14 \mathrm{~d}$ after adjuvant injection, with the lesion score in AA rats administered $40 \mathrm{mg} / \mathrm{kg} \mathrm{IMC}_{\text {nano }}$ tending to be higher than that in AA rats administered $40 \mathrm{mg} / \mathrm{kg} \mathrm{IMC}_{\text {micro }}$. Following the administration of $8 \mathrm{mg} / \mathrm{kg} \mathrm{IMC}$ nano, a dose given in consideration of the increased bioavailability in the case of the $\mathrm{IMC}_{\text {nano }}$ preparation, the lesion areas were significantly less than in the case of $40 \mathrm{mg} / \mathrm{kg} \mathrm{IMC}_{\text {micro }}$. In addition, the iNOS mRNA and $\mathrm{NO}$ levels in the gastric mucosa and small intestines of AA rats administered $8 \mathrm{mg} / \mathrm{kg} \quad \mathrm{IMC}_{\text {nano }}$ were also clearly lower than in the case of $40 \mathrm{mg} / \mathrm{kg} \mathrm{IMC}_{\text {micro }}$ administration (iNOS mRNA, gastric mucosa, $8 \mathrm{mg} / \mathrm{kg} \mathrm{IMC}_{\text {nano }} 0.46 \pm 0.19,40 \mathrm{mg} /$ $\mathrm{kg} \mathrm{IMC}$ micro $1.87 \pm 0.28$, small intestine, $8 \mathrm{mg} / \mathrm{kg} \mathrm{IMC}_{\text {nano }}$ $1.01 \pm 0.29, \quad 40 \mathrm{mg} / \mathrm{kg} \quad \mathrm{IMC}_{\text {micro }} 4.94 \pm 0.42, \mathrm{iNOS} / \mathrm{GAPDH}$, means \pm S.E., $n=3-5$ ). Figure 5 shows the amounts of IMC in the mucosal membrane of stomach and small intestine of AA rats following the oral administration of $\mathrm{IMC}_{\text {micro }}$ and $\mathrm{IMC}_{\text {nano }} 14 \mathrm{~d}$ after adjuvant injection. IMC was detected in the mucosal membrane of stomach and small intestine following the administration of $\mathrm{IMC}_{\text {micro }}$ and $\mathrm{IMC}_{\text {nano }}$ for $12 \mathrm{~h}$, 

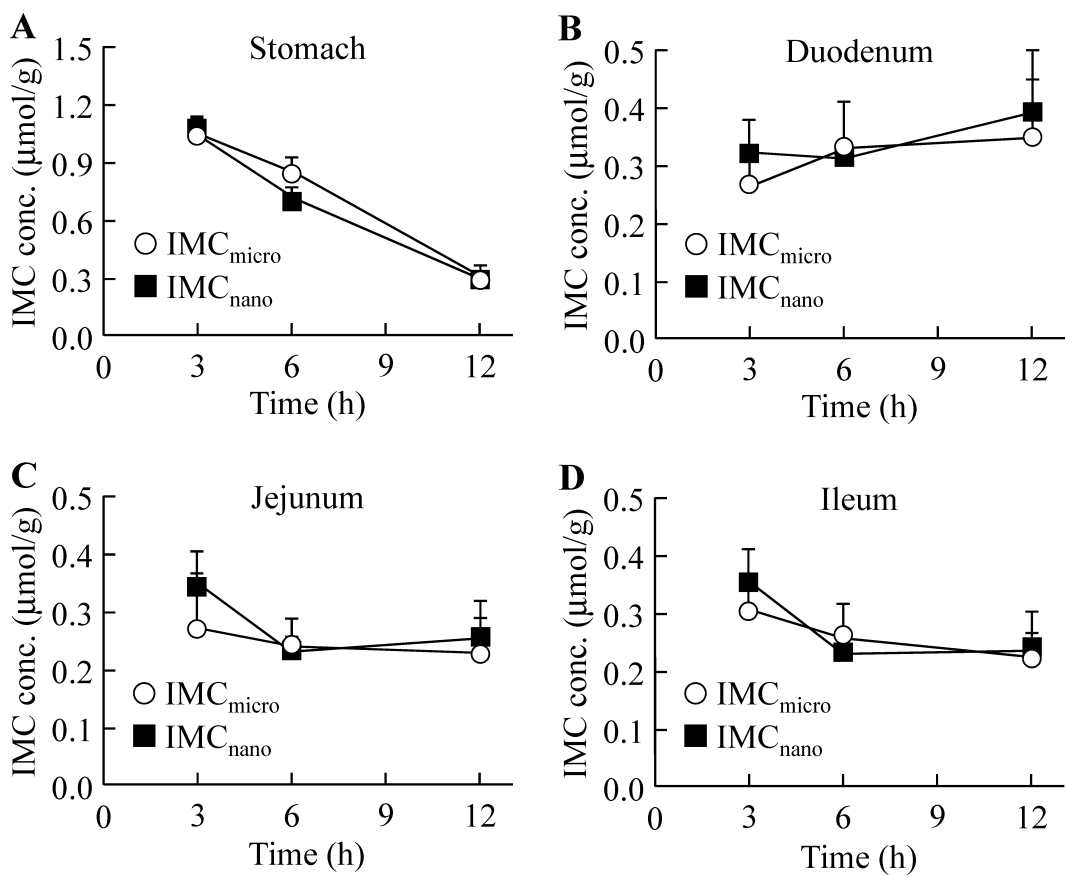

Fig. 5. Changes in IMC Amount in Mucosal Membrane of Stomach (A), Duodenum (B), Jejunum (C) and Ileum (D) Following the Oral Administration of $\mathrm{IMC}_{\text {micro }}$ or $\mathrm{IMC}_{\text {nano }}$

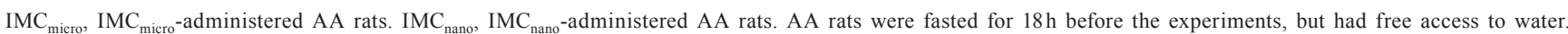
The rats were administered $\mathrm{IMC}_{\text {micro }}$ or $\mathrm{IMC}_{\text {nano }}(40 \mathrm{mg} / \mathrm{kg})$ orally, and killed under deep ether anesthesia 3,6 or $12 \mathrm{~h}$ later. The data are presented as means \pm S.E. of 5 independent rats.

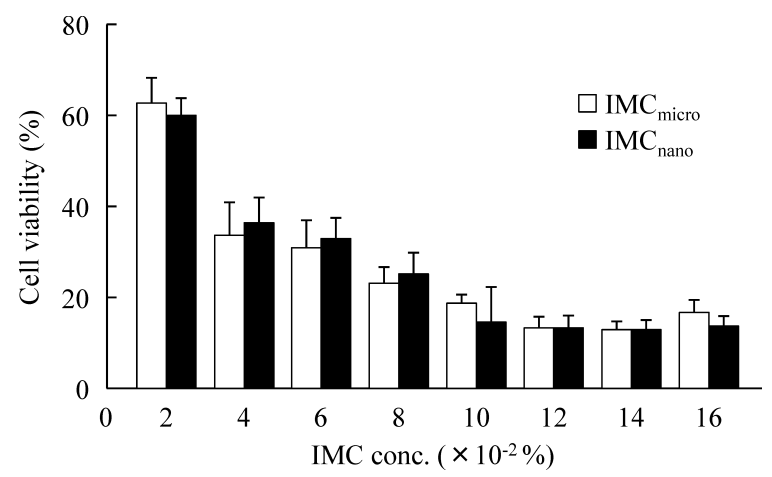

Fig. 6. Effects of $\mathrm{IMC}_{\text {micro }}$ and $\mathrm{IMC}_{\text {nano }}$ on the Viability of Caco-2 Cells

Caco-2 cells were incubated in medium containing $\mathrm{IMC}_{\text {micro }}$ or $\mathrm{IMC}_{\text {nano }}$ for $24 \mathrm{~h}$. Cell viability was calculated using TetraColor One according to Eq. 9 in Materials and Methods. The data are presented as means \pm S.E. of $5-10$ experiments.

and the amounts in the mucosal membrane of stomach and small intestine were similar between $\mathrm{IMC}_{\text {micro }}$ and $\mathrm{IMC}_{\text {nano }}$ administration. The amount of IMC in mucosal membrane of the stomach reached a maximum $3 \mathrm{~h}$ after administration, and then decreased with time. On the other hand, the amounts of IMC in the mucosal membrane of small intestine remained constant during the period $3-12 \mathrm{~h}$ after administration. Figure 6 shows the changes in the viability of Caco-2 cells following treatment with $\mathrm{IMC}_{\text {micro }}$ and $\mathrm{IMC}_{\text {nano }}$. The viability of Caco-2 cells decreased with increasing IMC concentration, with the viabilities of Caco-2 cells treated with $\mathrm{IMC}_{\text {micro }}$ and $\mathrm{IMC}_{\text {nano }}$ being similar. The viabilities of Caco-2 cells treated with $0.04 \% \mathrm{IMC}_{\text {micro }}$ and $\mathrm{IMC}_{\text {nano }}$ were approximately $32.7 \%$ and $35.6 \%$, respectively.

Preventive Effects of the Oral Administration of $\mathrm{IMC}_{\text {micro }}$ and $\mathrm{IMC}_{\text {nano }}$ on Paw Edema in AA Rats Figure
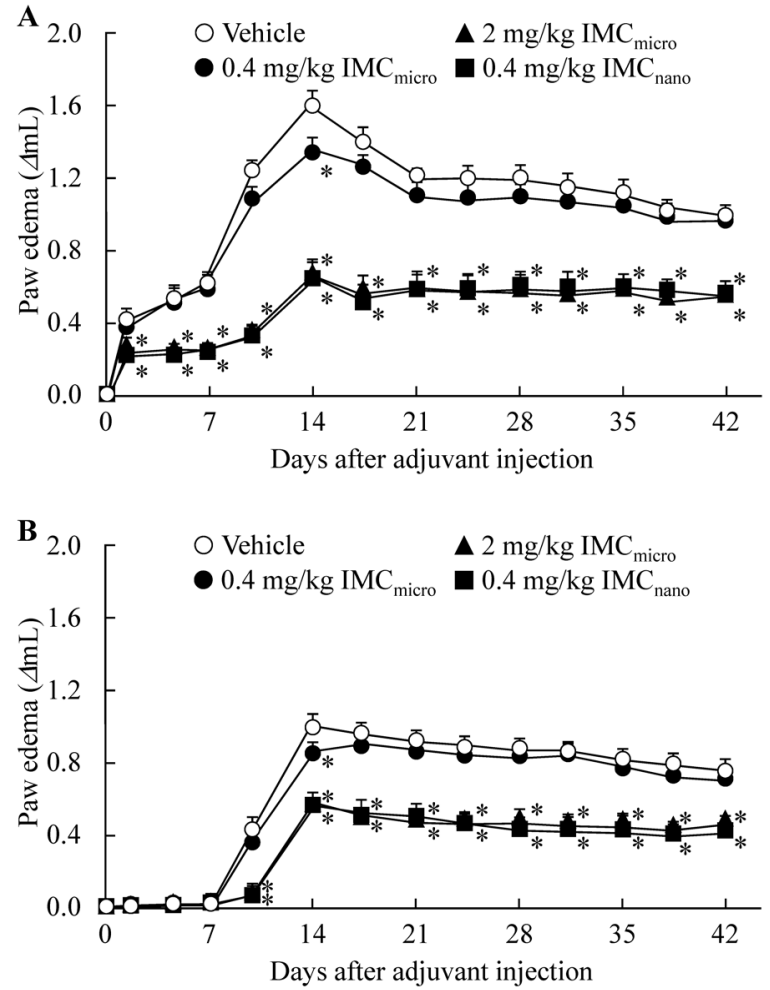

Fig. 7. Changes in Paw Edema of the Right (A) and Left (B) Hind Feet of AA Rats Administered $\mathrm{IMC}_{\text {micro }}$ or $\mathrm{IMC}_{\text {nano }}$

$\mathrm{IMC}_{\text {micro }}$ and $\mathrm{IMC}_{\text {nano }}$, a low dose $(0.4 \mathrm{mg} / \mathrm{kg})$ or therapeutic dose $(2 \mathrm{mg} / \mathrm{kg})$, was administered orally to rats once a day starting on the day following adjuvant injection. Treatments were continued for $42 \mathrm{~d}$ after adjuvant injection. The data are presented as means \pm S.E. of $5-10$ in dependent rats. $* p<0.05 v s$. vehicle-administered rats. 
Table 3. Effects of $\mathrm{IMC}_{\text {nano }}$ on Paw Edema in AA Rats

\begin{tabular}{lll}
\hline \hline & \multicolumn{2}{c}{$A U C_{\text {edema }}(\mathrm{mL} \cdot \mathrm{d})$} \\
\cline { 2 - 3 } & \multicolumn{1}{c}{ Right } & \multicolumn{1}{c}{ Left } \\
\hline Vehicle & $47.87 \pm 1.77$ & $31.56 \pm 1.13$ \\
$\mathrm{IMC}_{\text {micro }}(0.4 \mathrm{mg} / \mathrm{kg})$ & $43.99 \pm 1.83^{*}$ & $27.10 \pm 0.94^{*}$ \\
$\mathrm{IMC}_{\text {micro }}(2 \mathrm{mg} / \mathrm{kg})$ & $22.13 \pm 1.81^{*, * *}$ & $17.80 \pm 1.05^{*, * *}$ \\
$\mathrm{IMC}_{\text {nano }}(0.4 \mathrm{mg} / \mathrm{kg})$ & $21.62 \pm 1.76^{*, * *}$ & $16.97 \pm 0.99^{*, * *}$ \\
\hline
\end{tabular}

Dispersions containing IMC as described in Table 1 were administered orally to AA rats once a day starting on the day following adjuvant injection. Parameters $\left(A U C_{\text {edema }}\right)$ were calculated according to Eq. 2 (see Materials and Methods). $\mathrm{IMC}_{\text {micro }}$ $\mathrm{IMC}_{\text {micro }}$-administered $\mathrm{AA}$ rats; $\mathrm{IMC}_{\text {nano }}, \mathrm{IMC}_{\text {nano }}$-administered $\mathrm{AA}$ rats. The data are presented as means \pm S.E. of 5 independent rats. ${ }^{*} p<0.05 v s$. vehicle. $* * p<0.05 v$ s. $0.4 \mathrm{mg} / \mathrm{kg} \mathrm{IMC}_{\text {micro }}$

7 shows the changes in paw edema in the right (A) and left (B) hind feet of $\mathrm{AA}$ rats administered $\mathrm{IMC}_{\text {micro }}$ or $\mathrm{IMC}_{\text {nano. }}$ $\mathrm{IMC}_{\text {micro }}$ or $\mathrm{IMC}_{\text {nano }}$ at a low dose $(0.4 \mathrm{mg} / \mathrm{kg})$ or therapeutic dose $(2 \mathrm{mg} / \mathrm{kg})$ was administered orally to rats once a day starting on the day following adjuvant injection, and Table 3 shows the $A U C_{\text {edema }}$ values. Paw edema in the right hind foot, into which adjuvant was injected, appeared on the day following injection, and reached a maximum $14 \mathrm{~d}$ after injection. On the other hand, paw edema in the left hind foot, which was not injected with adjuvant, was not observed during the first $7 \mathrm{~d}$ after adjuvant injection, but clearly increased from $10 \mathrm{~d}$. Fourteen days after adjuvant injection, paw edema in the right and left hind feet of AA rats administered $0.4 \mathrm{mg} / \mathrm{kg} \mathrm{IMC}_{\text {micro }}$ was significantly less than in AA rats administered vehicle, and paw edema in the right and left hind feet of AA rats administered $2 \mathrm{mg} / \mathrm{kg} \mathrm{IMC} \mathrm{IM}_{\text {micro }}$ was significantly less than in rats receiving $0.4 \mathrm{mg} / \mathrm{kg} \mathrm{IMC}_{\text {micro }}$. The $A U C_{\text {edema }}$ values in the right and left hind feet of $\mathrm{AA}$ rats administered $2 \mathrm{mg} / \mathrm{kg} \mathrm{IMC}_{\text {micro }}$ were $46.2 \%$ and $56.4 \%$ those of AA rats administered vehicle, respectively. Furthermore, paw edema in the right and left hind feet of AA rats administered $0.4 \mathrm{mg} / \mathrm{kg} \mathrm{IMC}$ nano was significantly less than in AA rats receiving vehicle; paw edema and $A U C_{\text {edema }}$ values for AA rats receiving $0.4 \mathrm{mg} / \mathrm{kg} \mathrm{IMC}$ nano were similar to those for AA rats receiving $2 \mathrm{mg} / \mathrm{kg} \mathrm{IMC}_{\text {micro }}$.

\section{DISCUSSION}

IMC, [1-(4-chlorobenzoyl)-5-methoxy-2-methylIMCol-3-yl] acetic acid, molecular weight $357.8, \mathrm{p} K_{\mathrm{a}} 4.5$, is practically insoluble in water, but has been used as a therapy for RA patients. Gastrointestinal lesions are the most common side effect in patients taking IMC, and RA patients taking IMC are more susceptible to IMC-induced gastric lesions in comparison with other patients. ${ }^{3-7,9)}$ Therefore, the development of IMC formulations that do not cause gastrointestinal lesions is highly anticipated. In this study, we designed new oral formulations containing IMC solid nanoparticles, and investigated their usefulness by evaluating drug bioavailability and the toxicity (gastric and small intestinal ulcerogenic responses to IMC).

First, we attempted to mill IMC microparticles further by the bead mill method, but the mean particle size remained on the micro order (Milled-IMC, Fig. 1B); therefore, new innovations to regulate IMC particles were required, so we searched for useful additives to aid the performance of the bead mill. $\mathrm{MC}$, a derivative of cellulose, is a water-soluble substance with a high degree of purity, uniformity and transparency. MC molecules link to water molecules by intermolecular hydrogen bonds to form a cage-like structure, and such MC solutions are neutral, odorless and tasteless. MC solutions are also stable over the $\mathrm{pH}$ range, ${ }^{29)}$ and it is not necessary to remove the gel following the complete release of a drug. ${ }^{30)} \mathrm{MC}$ is highly biocompatible ${ }^{31-33)}$ and is used to prepare drug formulations. The gel strength depends on the degree of substitution and the molecular weight. ${ }^{34,35)}$ The particle size of IMC was decreased using a combination of MC addition and the bead mill method with the obtained IMC particles having a mean particle size of $190 \pm 110 \mathrm{~nm}$ (Milled-IMC $\mathrm{MC}_{\mathrm{M}+}$, mean \pm S.D.).

Next, the stability of dispersions containing IMC was demonstrated. The $\mathrm{IMC}_{\text {micro }}$ preparation precipitated $4 \mathrm{~h}$ after preparation. The precipitation was related the big particle size (weight) of $\mathrm{IMC}_{\text {micro }}$. The stability of drug dispersions in IMC formulation (Milled- $\mathrm{IMC}_{\mathrm{MC}+}$ ) was improved by the combination of MC addition and the bead mill method; however, precipitation was still observed $2 \mathrm{~d}$ after preparation (Fig. 2, Table 1). Mori et $a l .{ }^{36)}$ reported that adsorption to the surface of cyclodextrin decreases the cohesion of nanoparticulate solids, and we previously reported that the addition of $\mathrm{HP} \beta \mathrm{CD}$ to the mixture is suitable for the preparation of nanoparticles using mill methods. ${ }^{23,24)}$ Therefore, we attempted to prepare an IMC dispersion containing $0.5 \% \mathrm{MC}$ and $5 \% \mathrm{HP} \beta \mathrm{CD}$ using the bead mill method. HP $\beta$ CD was found to enhance the stability of the IMC dispersion $\left(\mathrm{IMC}_{\text {nano }}\right)$, and no precipitation was observed $14 \mathrm{~d}$ after preparation (Table 1). In addition, there was no difference in the particle size of $\mathrm{IMC}_{\text {nano }}$ between 0 and $14 \mathrm{~d}$ after preparation, and the addition of $\mathrm{HP} \beta \mathrm{CD}$ was also found to enhance the recovery percentage of IMC by the bead mill method (Milled-IMC $\mathrm{IC}_{\mathrm{MC}} 73.2 \pm 4.1 \%, \mathrm{IMC}_{\text {nano }} 93.5 \pm$ $3.3 \%$, means \pm S.E., $n=5$ ). The size of $\mathrm{HP} \beta \mathrm{CD}$ (approximately

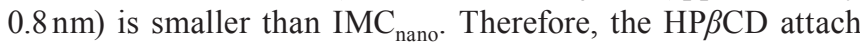
the surface of IMC nanoparticles, and may enhance the stability.

In this study, we investigated whether the IMC in $\mathrm{IMC}_{\text {nano }}$ and $\mathrm{IMC}_{\text {nano }}$ penetrated the membrane of small intestine by using the in vivo study (Fig. 3). The serum IMC level, absorption rate constant $\left(k_{\mathrm{a}}\right), A U C$ and $A U M C$ for AA rats administered $2 \mathrm{mg} / \mathrm{kg} \mathrm{IMC}_{\text {nano }}$ (therapeutic dose) were significantly higher than those for rats administered $2 \mathrm{mg} / \mathrm{kg} \mathrm{IMC} \mathrm{Imicro}_{\text {, and }}$ the $T_{\max }$ for $\mathrm{IMC}_{\text {nano }}$ was faster than that for $\mathrm{IMC}_{\text {micro }}$ (Table 2). In addition, the $A U C$ of serum IMC following the administration of low dose $\mathrm{IMC}_{\text {nano }}(0.4 \mathrm{mg} / \mathrm{kg})$ was similar to that following the administration of therapeutic dose $\mathrm{IMC}_{\text {micro }}(2 \mathrm{mg} /$ $\mathrm{kg}$ ), and the bioavailability for $0.4 \mathrm{mg} / \mathrm{kg} \mathrm{IMC}$ nano was 5.3 -fold higher than that of $2 \mathrm{mg} / \mathrm{kg} \mathrm{IMC}_{\text {micro }}$ (Table 2). Furthermore, the particle size of $\mathrm{IMC}_{\text {nano }}$ was $85 \pm 67 \mathrm{~nm}$ (means \pm S.E.) in the pH 1.2 buffer based on Japanese Pharmacopoeia (JP) test protocols. These results show that the amount of IMC administered as RA therapy can be reduced by using $\mathrm{IMC}_{\text {nano. It }}$ important to clarify the mechanism for the BA enhancement by nanoparticles. The solubility of $\mathrm{IMC}_{\text {nano }}$ may be increased in the in vivo, since the specific surface in nanoparticles is larger than that in microparticles. Moreover, we reported that the $\mathrm{HP} \beta \mathrm{CD}$ was increased the absorption via membrane. ${ }^{37)}$ Taking these findings together, we hypothesis that high solubility of $\mathrm{IMC}_{\text {nano }}$ caused the enhancement of BA.

In studies to identify the mechanisms of NSAIDs-induced gastrointestinal lesions in RA, the selection of an experimental animal is very important. The AA rat is an animal model 
in which arthritis is induced by the injection of an adjuvant. Inflammatory pain during the development of AA is assessed by measuring paw volume (paw edema). ${ }^{38,39)}$ Paw edema in AA rats is known to involve two inflammatory stages, primary and secondary inflammation. The primary inflammation starts from the day following the injection of adjuvant into the right hind foot. Secondary inflammation is observed from $7 \mathrm{~d}$ after adjuvant injection, and inflammation reaches a maximum $14 \mathrm{~d}$ after adjuvant injection into the right and/or left hind foot. $^{3,7)}$ In addition, it has been reported that gastrointestinal lesions induced by conventional NSAIDs, such as indomethacin, naproxen and aspirin, are significantly aggravated in AA rats as compared with normal rats. It is noteworthy that changes in the biological characteristics of AA rats correspond to those that occur in human RA. ${ }^{3,5,6,38,39)}$ Therefore, AA rats may provide a useful model for studies on the mechanisms of NSAIDs-induced gastrointestinal lesions in RA. It is known that the severity of arthritis in Wistar rats is moderate and occurs with an incidence of only $50-60 \%$. On the other, the severity of arthritis in DA and Lewis rats is much higher than in Wistar rats, and occurs with an incidence of $100 \% .^{3,5-7)}$ Therefore, in this study we investigated the effect of orally administered IMC solid nanoparticles on drug bioavailability and the gastric and small intestinal ulcerogenic responses to NSAIDs using IMC-administered DA rats injected with adjuvant.

The oral administration of $\mathrm{IMC}_{\text {micro }}$ or $\mathrm{IMC}_{\text {nano }}(40 \mathrm{mg} /$ $\mathrm{kg}$ ) resulted in the formation of hemorrhagic lesions in both the gastric mucosa and small intestine of AA rats $14 \mathrm{~d}$ after adjuvant injection, and the lesion score at AA rats adminis-

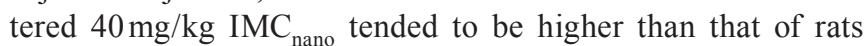

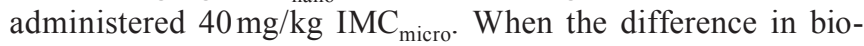
availability was taken into account, and the dose of $\mathrm{IMC}_{\text {nano }}$ was reduced to $8 \mathrm{mg} / \mathrm{kg}$, the lesion area in rats administered $\mathrm{IMC}_{\text {nano }}$ was significantly less in rats administered $40 \mathrm{mg} / \mathrm{kg}$ $\mathrm{IMC}_{\text {micro }}$ (Fig. 4), while the fates of serum IMC were similar $\left(8 \mathrm{mg} / \mathrm{kg} \mathrm{IMC}_{\text {nano }}: A U C, 453.0 \pm 54.7 \mathrm{nmol} / \mathrm{mL} \cdot \mathrm{h}\right.$ mean \pm S.E. $n=5 ; 40 \mathrm{mg} / \mathrm{kg} \mathrm{IMC}{ }_{\text {micro }}: A U C, 441.9 \pm 44.1 \mathrm{nmol} / \mathrm{mL} \cdot \mathrm{h}$, mean士 S.E. $n=5)$. In addition, the in situ loop experiment, the intestinal penetration in $\mathrm{IMC}_{\text {nano }}$ increased with time; however, there was little permeation in the case of $\mathrm{IMC}_{\text {micro }}$ found (the IMC levels 40 min after the injection of $\mathrm{IMC}_{\text {micro }}$ were only $1.3 \%$ those of the levels following the injection of $\mathrm{IMC}_{\text {nano, }}$, $n=5)$. Also, the iNOS mRNA and NO levels in the gastric mucosa and small intestine of AA rats administered $8 \mathrm{mg} / \mathrm{kg}$ $\mathrm{IMC}_{\text {nano }}$ were clearly lower than in rats administered $40 \mathrm{mg} / \mathrm{kg}$ $\mathrm{IMC}_{\text {micro. }}$ It is known that the overproduction of NO plays a key pathogenic role in both the gastric and small intestinal ulcerogenic responses to IMC in RA patients. ${ }^{3,5-7)}$ Furthermore, we showed that the amounts of IMC in the mucosal membrane of stomach and small intestine of AA rats following the oral administration of $\mathrm{IMC}_{\text {micro }}$ and $\mathrm{IMC}_{\text {nano }} 14 \mathrm{~d}$ after adjuvant injection was similar (Fig. 5), and the cell stimulation by $\mathrm{IMC}_{\text {micro }}$ and $\mathrm{IMC}_{\text {nano }}$ were similar in the in vitro study (Fig. 6). These results show that the high IMC concentration in blood and intensity of cell stimulation relate the gastrointestinal toxicity by the oral administration of $\mathrm{IMC}_{\text {micro }}$ and $\mathrm{IMC}_{\text {nano }}$. We conclude that treatment with low doses of $\mathrm{IMC}_{\text {nano }}$ may enable RA therapy without gastric and small intestinal ulcerogenic responses to NSAIDs. Moreover, paw edema of the right hind feet of AA rats receiving oral administration of low dose $\mathrm{IMC}_{\text {nano }}(0.4 \mathrm{mg} / \mathrm{kg})$ was signifi- cantly less in comparison with AA rats who received vehicle, and the paw edema and $A U C_{\text {edema }}$ values of AA rats receiving low doses $\mathrm{IMC}_{\text {nano }}(0.4 \mathrm{mg} / \mathrm{kg})$ was similar to that of AA rats receiving therapeutic dose $\mathrm{IMC}_{\text {micro }}(2 \mathrm{mg} / \mathrm{kg})$. These results show that the oral administration of $\mathrm{IMC}_{\text {nano }}$ for RA treatment can be kept at a low dose, since the drug bioavailability is higher than that of conventional IMC. In addition, the oral administration of $\mathrm{IMC}_{\text {nano }}$ provides therapy for RA with fewer IMC-induced gastrointestinal lesions.

Further studies are needed to elucidate the precise mechanism for the gastrointestinal toxicity of $\mathrm{IMC}_{\text {nano }}$ by hematoxylin-eosin (HE) staining. In addition, it is important to clarify the drug solubility of the IMC formulation and structure of the delivery system. Therefore, we are now investigating the structure of the delivery system for IMC nanoparticles by scanning electron microscopy.

In the present study, we attempted to establish a new method for the preparation of drug solid nanoparticles, and succeeded in preparing a high quality dispersion containing IMC nanoparticles (particle size, $76 \pm 58 \mathrm{~nm}$, mean \pm S.D.). It is possible that the oral administration of IMC nanoparticles will provide increased effectiveness in treating RA without the toxicity (gastric and small intestinal ulcerogenic responses to NSAIDs), and that an oral drug delivery system using drug nanoparticles may expand the usage of NSAIDs for therapy in the inflammatory field.

\section{REFERENCES}

1) Hultqvist M, Olofsson P, Gelderman KA, Holmberg J, Holmdahl R. A new arthritis therapy with oxidative burst inducers. PLoS Med., 3, e348 (2006).

2) Escandell JM, Recio MC, Manez S, Giner RM, Cerda-Nicholas M, Rios JL. Cucurbitacin R reduces the inflammation and bone damage associated with adjuvant arthritis in lewis rats by suppression of tumor necrosis factor-alpha in T lymphocytes and macrophages. $J$. Pharmacol. Exp. Ther., 320, 581-590 (2007).

3) Kato S, Takeuchi K. Alteration of gastric ulcerogenic and healing responses in rats with adjuvant-induced arthritis. Jpn. J. Pharmacol., 89, 1-6 (2002).

4) Maiden L, Thjodleifsson B, Theodors A, Gonzalez J, Bjarnason I. A quantitative analysis of NSAID-induced small bowel pathology by capsule enteroscopy. Gastroenterology, 128, 1172-1178 (2005).

5) Kato N, Mashita Y, Kato S, Mitsufuji S, Yoshikawa T, Takeuchi K. Sildenafil, an inhibitor of phosphodiesterase subtype 5, prevents indomethacin-induced small-intestinal ulceration in rats via a $\mathrm{NO} /$ cGMP-dependent mechanism. Dig. Dis. Sci., 54, 2346-2356 (2009).

6) Kato S, Ohkawa F, Ito Y, Amagase K, Takeuchi K. Role of endothelial nitric oxide synthase in aggravation of indomethacin-induced gastric damage in adjuvant arthritic rats. J. Physiol. Pharmacol., 60, 147-155 (2009).

7) Nagai N, Fukuhata T, Ito Y, Usui S, Hirano K. Involvement of interleukin 18 in indomethacin-induced lesions of the gastric mucosa in adjuvant-induced arthritis rat. Toxicology, 255, 124-130 (2009).

8) Bjarnason I. Gastrointestinal safety of NSAIDs and over-thecounter analgesics. Int. J. Clin. Pract. Suppl., 67 (Suppl. 178), 37-42 (2013).

9) Fries JF, Miller SR, Spitz PW, Williams CA, Hubert HB, Bloch DA. Toward an epidemiology of gastropathy associated with nonsteroidal antiinflammatory drug use. Gastroenterology, 96 (Suppl.), 647-655 (1989).

10) Vane JR. Inhibition of prostaglandin synthesis as a mechanism of action for aspirin-like drugs. Nat. New Biol., 231, 232-235 (1971). Whittle BJ, Laszlo F, Evans SM, Moncada S. Induction of nitric 
oxide synthase and microvascular injury in the rat jejunum provoked by indomethacin. Br. J. Pharmacol., 116, 2286-2290 (1995).

12) Weissenborn U, Maedge S, Buettner D, Sewing KF. Indomethacinincreased gastrointestinal lesions in relation to tissue concentration, food intake and bacterial invasion in the rat. Pharmacology, 30, 32-39 (1985).

13) Asako H, Kubes P, Wallace J, Gaginella T, Wolf RE, Granger DN. Indomethacin-induced leukocyte adhesion in mesenteric venules; role of lipoxygenase products. Am. J. Physiol., 262, G903-G908 (1992).

14) Yamada T, Deitch E, Specian RD, Perry MA, Sartor RB, Grisham MB. Mechanisms of acute and chronic intestinal inflammation induced by indomethacin. Inflammation, 17, 641-662 (1993).

15) Konaka A, Nishijima M, Tanaka A, Kunikata T, Kato S, Takeuchi K. Nitric oxide, superoxide radicals and mast cells in pathogenesis of indomethacin-induced intestinal lesions in rats. J. Physiol. Pharmacol., 50, 25-38 (1999).

16) Diebold Y, Jarrin M, Saez V, Carvalho ELS, Orea M, Calonge M, Seijo B, Alonso MJ. Ocular drug delivery by liposome-chitosan nanoparticle complexes (LCS-NP). Biomaterials, 28, 1553-1564 (2007).

17) Minko T, Rodriguez-Rodriguez L, Pozharov V. Nanotechnology approaches for personalized treatment of multidrug resistant cancers. Adv. Drug Deliv. Rev., 65, 1880-1895 (2013).

18) Sha S, Vong LB, Chonpathompikunlert P, Yoshitomi T, Matsui H, Nagasaki Y. Suppression of NSAID-induced small intestinal inflammation by orally administered redox nanoparticles. Biomaterials, 34, 8393-8400 (2013).

19) Cohen S, Yoshioka T, Lucarelli M, Hwang LH, Langer R. Controlled delivery systems for proteins based on poly(lactic/glycolic acid) microspheres. Pharm. Res., 8, 713-720 (1991).

20) Tomoda $K$, Terashima $H$, Suzuki $K$, Inagi $T$, Terada H, Makino $\mathrm{K}$. Enhanced transdermal delivery of indomethacin-loaded PLGA nanoparticles by iontophoresis. Colloids Surf. B Biointerfaces, $\mathbf{8 8}$, 706-710 (2011).

21) Tomoda K, Terashima H, Suzuki K, Inagi T, Terada H, Makino K. Enhanced transdermal delivery of indomethacin using combination of PLGA nanoparticles and iontophoresis in vivo. Colloids Surf. $B$ Biointerfaces, 92, 50-54 (2012).

22) Tomoda K, Watanabe A, Suzuki K, Inagi T, Terada H, Makino K. Enhanced transdermal permeability of estradiol using combination of PLGA nanoparticles system and iontophoresis. Colloids Surf. $B$ Biointerfaces, 97, 84-89 (2012).

23) Nagai N, Ito Y. Therapeutic effects of gel ointments containing tranilast nanoparticles on paw edema in adjuvant-induced arthritis rats. Biol. Pharm. Bull., 37, 96-104 (2014).

24) Nagai N, Ono H, Hashino M, Ito Y, Okamoto N, Shimomura Y. Improved corneal toxicity and permeability of tranilast by the preparation of ophthalmic formulations containing its nanoparticles. J. Oleo Sci., 63, 177-186 (2014).

25) Ito $\mathrm{Y}$, Ogiso T, Iwaki M, Tanino T, Terao M. Percutaneous absorp- tion of acemetacin from a membrane controlled transdermal system and prediction of the disposition of the drug in rats. Biol. Pharm. Bull., 16, 583-588 (1993).

26) Barr WH, Riegelman S. Intestinal drug absorption and metabolism. I. Comparison of methods and models to study physiological factors of in vitro and in vivo intestinal absorption. J. Pharm. Sci., 59, 154-163 (1970).

27) Windmueller HG, Spaeth AE. Intestinal metabolism of glutamine and glutamate from the lumen as compared to glutamine from blood. Arch. Biochem. Biophys., 171, 662-672 (1975).

28) Bradford MM. A rapid and sensitive method for the quantitation of microgram quantities of protein utilizing the principle of proteindye binding. Anal. Biochem., 72, 248-254 (1976).

29) Lin CP, Boehnke M. Influences of methylcellulose on corneal epithelial wound healing. J. Ocul. Pharmacol. Ther., 15, 59-63 (1999).

30) Lin Y, Sun J, Jiang G, Zan J, Ding F. In vitro evaluation of lysozyme-loaded microspheres in thermosensitive methylcellulosebased hydrogel. Chin. J. Chem. Eng., 15, 566-572 (2007).

31) Wells MR, Kraus K, Batter DK, Blunt DG, Weremowitz J, Lynch SE, Antoniades HN, Hansson HA. Gel matrix vehicles for growth factor application in nerve gap injuries repaired with tubes: a comparison of biomatrix, collagen, and methylcellulose. Exp. Neurol., 146, 395-402 (1997).

32) Tate MC, Shear DA, Hoffman SW, Stein DG, LaPlaca MC. Biocompatibility of methylcellulose-based constructs designed for intracerebral gelation following experimental traumatic brain injury. Biomaterials, 22, 1113-1123 (2001).

33) Gupta D, Tator CH, Shoichet MS. Fast-gelling injectable blend of hyaluronan and methylcellulose for intrathecal, localized delivery to the injured spinal cord. Biomaterials, 27, 2370-2379 (2006).

34) Kundu PP, Kundu M. Effect of salts and surfactant and their doses on the gelation of extremely dilute solutions of methyl cellulose. Polymer (Guildf.), 42, 2015-2020 (2001).

35) Sanz T, Fernandez MA, Salvador A, Munoz J, Fiszman SM. Thermogelation properties of methylcellulose (MC) and their effect on a batter formula. Food Hydrocolloids, 19, 141-147 (2005).

36) Mori K, Yoshioka N, Kondo Y, Takeuchi T, Yamashita H. Catalytically active, magnetically separable, and water-soluble $\mathrm{FePt}$ nanoparticles modified with cyclodextrin for aqueous hydrogenation reactions. Green Chem., 11, 1337-1342 (2009).

37) Ito Y, Nagai N, Okamoto N, Shimomura Y, Nakanishi K, Tanaka R. Reduction of enhanced rabbit intraocular pressure by instillation of pyroglutamic acid eye drops. Biol. Pharm. Bull., 36, 1017-1023 (2013)

38) Billingham ME. Models of arthritis and the search for anti-arthritic drugs. Pharmacol. Ther., 21, 389-428 (1983).

39) Sakuma S, Nishigaki F, Magari K, Ogawa T, Miyata S, Ohkubo Y, Goto T. FK506 is superior to methotrexate in therapeutic effects on advanced stage of rat adjuvant-induced arthritis. Inflamm. Res., 50, 509-514 (2001). 